\title{
Original Clinical characteristics and outcome in children Article with convulsive status epilepticus
}

\section{Pediatrics}

Areej M. Mohammad ${ }^{1}$, Eman M. Khaled ${ }^{1}$, Marwa Elhady ${ }^{1}$, Asmaa S. Hassan ${ }^{2}$

${ }^{1}$ Pediatric Department, Faculty of Medicine for Girls, Cairo, Al-Azhar University, Egypt.

${ }^{2}$ Clinical Pathology Department, Faculty of Medicine for Girls Cairo, Al-Azhar, University, Egypt.

\section{ABSTRACT}

Background: Status epilepticus (SE) is a serious neurological emergency that is associated with increased morbidity and mortality. There is emerging interest in understanding the clinical characteristics and identification of the prognosis of children with SE.

Objective: To identify the clinical profile and prognosis of children presenting by status epilepticus.

Methodology: This is a descriptive analytical study carried out on 31 children who presented by convulsive SE and were admitted to the pediatric intensive care unit. Clinical data, Complete blood count, C-reactive protein, erythrocyte sedimentation rate, serum glucose \& electrolytes and cerebrospinal fluid analysis were estimated. Magnetic resonance imaging was done to all included children.

Results: Most of the children who presented with SE were younger than 5 years of age $(45.2 \%$ were $<2$ years and $32.2 \%$ were $2-5$ years). $74.2 \%$ were males and $83.9 \%$ had generalized seizures. $29 \%$ had SE as a first presentation. $77.4 \%$ were known cases of epilepsy. Non epileptic causes included encephalitis (12.9\%), febrile convulsion (a typical) $(6.5 \%)$ and acute hypoxia(shocking) (3.2\%). The main precipitating factors for SE were missing doses in $29 \%$, acute febrile Illness in $12.9 \%$, acute hypoxia in $6.5 \%$, while precipitating factors could not be identified in $41.9 \%$ of children. Most children had normal MRI (64.5\%). The commonest abnormalities were diffuse hypoxia and encephalitis ( $12.9 \%$ for each). $70.9 \%$ of children survived without neurological sequeals, $19.4 \%$ developed neurological sequels while $9.7 \%$ died. Non-epileptic etiology, febrile illness, hypoxia, elevated acute phase reactant (erythrocytes sedimentation rate and C-reactive protein) was significantly associated with poor outcome.

Conclusion: Despite that epilepsy is the main cause of SE, non-epileptic causes are more serious and are associated with a worser outcome. Male gender, poor compliance to antiepileptic medications and febrile illness are linked to the development of SE in children. SE induced by hypoxia and encephalitis had the highest morbidity and mortality.

JRAM 2021; 2(2):194-203

Key words: Status epileptics, seizures, outcome, children

Submission Date: 19 February 2021

Acceptance Date: 14 March 2021

Corresponding author: Marwa Elhady, Pediatric department, faculty of medicine for girls, Cairo, Al-Azhar University, Egypt. Tel: 01022414667. E-mail: marwaelhady93@yahoo.com

Please cite this article as: Mohammad AM, Khaled EM, Elhady M, Hassan A. Clinical Characteristics and Outcome in Children with convulsive Status Epilepticus. JRAM 2021; 2(2):194-203. DOI: 10.21608/jram.2021.63973.1111

\section{INTRODUCTION}

Status Epilepticus (SE) is a major acute, lifethreatening neurological emergency. It may be an initial presentation of many neurological disorders in children. The overall incidence of pediatric SE is roughly 20 per 100,000 children per year, with overall mortality of $3 \%{ }^{[1]}$ The International League Against Epilepsy (ILAE) defines SE as "a seizure caused by failure of the mechanisms that terminate seizure activity or development of mechanisms that induce abnormally prolonged seizure activity that shows no clinical signs of arresting after a duration encompassing the great majority of seizures of that type in most patients or recurrent seizures without interictal resumption of baseline central nervous system function causing a risk of long-term consequences (this time point is defined as $\mathbf{3 0}$ minutes after initiation of seizure activity" ${ }^{[2]}$.

Status Epilepticus represent a heterogeneous rather than a single entity disorder that include many electroclinical syndromes with different etiologies and several triggering factors. Despite advance in treatment, it is still associated with significant neuro-morbidity and mortality. Neuronal damage is a serious sequel if seizures are not promptly controlled ${ }^{[3]}$ Mechanisms of neuronal injury includes combination of direct damage 
from seizure-related activity (excitotoxicity) and secondary effects of the associated metabolic cascade, hypoxia, oxidative stress and activation of inflammatory signals. Seizures exceeding 30 minutes duration are associated with long-term consequences including neuronal death, neuronal injury, and altered neuronal networks ${ }^{[4]}$.

Children are vulnerable group as human brain undergoes rapid growth and maturation in early years of life which continue throughout adolescence. Prolonged seizure activity adversely affects the brain structure and function. Early initiation of treatment is a major step in management aiming to abort seizures activity ${ }^{[5]}$.

Prognosis of children who develop SE it is significantly affected by duration of seizures, seizure types and underlying etiology, in addition to the child age and associated comorbidities. Identifying children at greater risk for development of neurological sequels is an emerging area of research with conflicting findings ${ }^{[6]}$. The current study aimed to identify the clinical profile and prognosis of children presentedby status epilepticus.

\section{PATIENTS AND METHOD}

The present study is a cross sectional descriptive analytical study. It was carried out on 31 children presented by status epilepticus who were admitted to pediatric intensive care unit (PICU). Children were recruited consecutively from the PICU of Al-Galaa and Ghamra military hospital during the period from November 2018 to July 2020. A written informed consent was received from parents of included children after explaining the aim and outcome of the study. The protocol of the study was approved by local ethics committee at faculty of medicine for girls, Al-Azhar University (IRB 202103714).

\section{Inclusion criteria:}

1. Age group from 1 month to 18 years. 2- Both sexes were included

2. Patients presented by convulsive status epilepticus according to definition of status epileptics from the International League Against Epilepsy (ILAE) ${ }^{[2]}$

\section{Exclusion criteria:}

1. Children presented with short duration seizure that did not fulfill the criteria for status epilepticus.

2. Seizures caused by drug or chemical poisoning.

3. Seizures caused by inborn errors of metabolism (based on history, examination, and MRI findings)

4. Seizures caused by non-neurological disorders (e.g., hepatic, renal, hypoglycemia,electrolytes disturbances, or psychological diseases)

5. Post-concussion cases or traumatic brain insults
All patients were subjected to:

I. Detailed history taking including:

- History suggestive of neurological disorders e.g., convulsions, headache, photophobia or behavioral changes, age of first seizures, precipitating factors, duration of previous seizures, and any previous episodes of status epilepticus.

- History suggestive of developmental delay or psychiatric disorders (e.g., ADHD, anxiety, depression disorders)

- History suggests inborn error of metabolism (developmental delay, failure to thrive, organomegally, intellectual disability)

- History of drug intake, antiepileptic therapy (dose, duration, and compliance)

- Family history including consanguinity, similar family condition or family history of neurological disease.

\section{Clinical assessment:}

- Thorough clinical examination was including all body systems with special emphasis on neurological system.

- Vital signs on admission and on regular basis during hospital stay.

- Full neurological examination focused on signs of lateralization, brain herniation, size and reactivity of the pupils, pattern of respiration and abnormal motor activity (flaccidity, decorticate or decerebrate rigidity) and Glasgow Coma Scale (GCS) was performed after cessation of convulsion attacks to identify those who did not regain consciousness after cessation of seizures.

NB: seizures were considered of unknown etiology (idiopathic epilepsy): if previously healthy, no abnormal neurological examination and normal neuroimaging) ${ }^{[2]}$.

\section{Electroencephalographic (EEG) monitoring} using digital EEG; NicoletOne, Natus Medical Incorporated (USA; 2014) was performed to all included children at admission to PICU to detect the abnormal EEG discharge and identify the type of seizures (generalized or focal).

III. Neuroimaging study: Magnetic resonance imaging after stabilization of the condition (using Philips Healthcare device, Holland, 2010).

\section{Laboratory investigations including:}

- Complete blood count (CBC): using Siemens SYSMEX XS-500 hematology analyzer.

- Erythrocyte sedimentation rate (ESR) \&Creactive protein (CRP): ESR: Using SD-1000 automated ESR analyzer. CRP: using Micro Analysis II multiple - channel dry- type fluoroimmunoassay quantitative analyzer.

- Kidney function test: serum urea, serum cretinine using the Automated Chemistry 


\section{Analyzer.}

- Liver function test: serum alanine aminotransferase (ALT), serum aspartate aminotransferase (AST). SGM Italia: Kit for measurement of alanine - aminotransferase in serum or plasma- Kinetic UV optimized method IFCC (international Federation of clinical chemistry and laboratory medicine).

- Serum glucose and electrolytes (sodium, potassium, calcium, and magnesium). Serum glucose was measured using Ion selective electrode (ISE) Parnassus: Nova 8 CRT Mt. Zion: Gem Premier 3500

- Arterial blood gases to determine PH, partial pressure of carbon dioxide and partial pressure of oxygen in the blood.

- CSF analysis for suspected cases of CNS infection: Usually three tubes are collected. The first is used for chemical and serological analysis and the last two tubes are used for hematology and microbiology tests.

All laboratory tests were done at the central laboratory of pediatric hospital, Galaa and Ghamra military hospitals.

\section{Statistical Analysis}

Data were tabulated and analyzed using statistical package for social science (SPSS Inc., Chicago, Illinois, USA) version 22. Numerical data were expressed as mean and standard deviation (SD) and non-numerical data were expressed as number and percentage. Comparison between groups was done using student t-test if normal distribution data and Mann Whitney $U$ test if non normal distribution of numerical data and chi square test for non-numerical data. Also, Pearson correlation coefficient (r) was used to measure the association between two quantitative variables. The level of significance was set as $\mathrm{P}$-value $<0.05$ (95\% confidence interval).

\section{RESULTS}

Among our included children, the age at presentation by SE ranged from 6 months to 11 years with mean age of $5.36 \pm 3.72$ years. Most of children presented by SE were younger than age of 5 years $(45.2 \%$ were $<2$ years and $32.2 \%$ were $2-5$ years). Regarding the gender, $74.2 \%$ were males. $29 \%$ had SE as 1 st presentation while the remaining $77.4 \%$ were known cases of epilepsy. $45 \%$ developed $1^{\text {st }}$ seizure at age younger than 2 years. The cause of seizures could not be detected in $51.6 \%$ of cases (idiopathic epilepsy), while secondary epilepsy represents $25.8 \%$ of cases. Non epileptic causes included encephalitis (12.9\%), febrile convulsion (atypical type) $(6.5 \%)$ and acute hypoxia (3.2\%). CSF analysis revealed that none of the studied children have meningitis. Based on electroencephalography, seizures were generalized in $83.9 \%$ of children and focalin $16.1 \%$ of them. Most of children were receiving AEDs (29\% on monotherapy and $41.9 \%$ on polytherapy). The main precipitating factor for SE were missing doses in $29 \%$ of children followed by acute febrile Illness in $12.9 \%$, inappropriate AEDs in $9.7 \%$ and acute hypoxia in $6.5 \%$ of them, while precipitating factor could not be identified in $41.9 \%$ of children. Regarding the clinical characteristics of seizures, $77.4 \%$ of children had continuous seizures for $>30$ minutes while $22.6 \%$ had recurrent seizures with impaired consciousness in between attacks for total duration exceed 30 minutes. In most cases $(54.8 \%)$, seizures were terminated by using three AEDs while 2 cases needed to add general anesthesia (table 1 and figures 1-3).

Regarding routine laboratory investigations among our studied children, the mean hemoglobin level was $10.90 \pm 1.86 \mathrm{mg} / \mathrm{dl}$, arterial blood gas revealed average $\mathrm{PH}$ of $7.36 \pm 0.10$, acute phase reactant was elevated in some cases: CRP ranged between $0.4-148 \mathrm{mg} / \mathrm{dl}$ and ESR ranged between 4-120 (table 2).

Regarding the MRI findings of children presented by SE, most of the children had normal MRI (64.5\%). The commonest abnormalities were diffuse hypoxia and encephalitis (12.9\% for each) followed by delayed myelination, focal cortical dysplasia, and mesial temporal sclerosis (3.2\% for each) (table 3$)$.

Regarding the outcome of studied children. $70.9 \%$ survives without neurological squeals, $19.4 \%$ developed neurological sequels (in the form of neurological motor defect, psychobehavioural impairment detected by clinical follow up for 3 months after SE) while $9.7 \%$ was died (table 4).

Comparison of clinical, laboratory, neuroimaging findings in relation to the outcome showed significant association between non epileptic etiology, febrile illness, hypoxia, elevated acute phase reactant (ESR, CRP) and poor outcome (table 5). 
Table (1): Clinical data of the studied children presented by status epilepticus $(n=31)$

\begin{tabular}{|c|c|}
\hline Clinical data & $(n=31)$ \\
\hline $\begin{array}{l}\text { Age (years) } \\
\text { Range } \\
\text { Mean } \pm \text { SD }\end{array}$ & $\begin{array}{c}2-11 \\
5.36 \pm 3.72\end{array}$ \\
\hline $\begin{array}{l}\text { Sex } \\
\text { Female } \\
\text { Male }\end{array}$ & $\begin{array}{l}8(25.8 \%) \\
23(74.2 \%)\end{array}$ \\
\hline $\begin{array}{l}\text { Age at } 1^{\text {st }} \text { seizure (years) } \\
\text { Range } \\
\text { Mean } \pm \text { SD }\end{array}$ & $\begin{array}{c}6 \text { months-7years } \\
2.45 \pm 2.59\end{array}$ \\
\hline $\begin{array}{l}\text { Age distribution at } \mathbf{1}^{\text {st }} \text { seizure } \\
<2 \text { years } \\
2-5 \text { years } \\
>5 \text { years }\end{array}$ & $\begin{array}{l}14(45.2 \%) \\
10(32.2 \%) \\
7(22.6 \%)\end{array}$ \\
\hline $\begin{array}{l}\text { Age distribution at SE } \\
<2 \text { years } \\
2-5 \text { years } \\
>5 \text { years }\end{array}$ & $\begin{array}{c}9(29.1 \%) \\
7(22.6 \%) \\
15(48.3 \%)\end{array}$ \\
\hline $\begin{array}{l}\text { Etiology of seizures } \\
\text { Idiopathic epilepsy (genetic, unknown etiology) } \\
\text { Secondary epilepsy (symptomatic) } \\
\text { Encephalitis } \\
\text { Febrile convulsion } \\
\text { Acute hypoxia }\end{array}$ & $\begin{array}{c}16(51.6 \%) \\
8(25.8 \%) \\
4(12.9 \%) \\
2(6.5 \%) \\
1(3.2 \%)\end{array}$ \\
\hline $\begin{array}{l}\text { Clinical characteristics of seizures } \\
\text { Continuous seizures for }>30 \text { minutes } \\
\text { Recurrent seizures with impaired consciousness }\end{array}$ & $\begin{array}{c}24(77.4 \%) \\
7(22.6 \%)\end{array}$ \\
\hline $\begin{array}{l}\text { Type of seizures (based on EEG) } \\
\text { Focal seizures } \\
\text { Generalized seizures }\end{array}$ & $\begin{array}{c}5(16.1 \%) \\
26(83.9 \%)\end{array}$ \\
\hline $\begin{array}{l}\text { Previous antiepileptic drugs } \\
\text { Mono therapy } \\
\text { Poly therapy } \\
\text { Not on AEDs }\end{array}$ & $\begin{array}{l}9(29.0 \%) \\
13(41.9 \%) \\
9(29.0 \%)\end{array}$ \\
\hline $\begin{array}{l}\text { Precipitating factors for SE: } \\
\text { Hypoxia } \\
\text { Inappropriate AED type } \\
\text { Febrile Illness } \\
\text { Missing Doses } \\
\text { Unknown }\end{array}$ & $\begin{array}{c}2(6.5 \%) \\
3(9.7 \%) \\
4(12.9 \%) \\
9(29.0 \%) \\
13(42 \%)\end{array}$ \\
\hline $\begin{array}{l}\text { Duration of convulsive seizures (hours) } \\
\text { Range } \\
\text { Mean } \pm \text { SD }\end{array}$ & $\begin{array}{c}30 \text { minutes }-5 \text { days } \\
8.19 \pm 6.65\end{array}$ \\
\hline $\begin{array}{l}\text { Antiepileptic drugs used to control seizures } \\
\text { Two AEDs } \\
\text { Three AEDs } \\
\text { >3 AEDS + general anesthesia }\end{array}$ & $\begin{aligned} 12 & (38.7 \%) \\
17 & (54.8 \%) \\
2 & (6.5 \%)\end{aligned}$ \\
\hline
\end{tabular}

SE: status epilepticus; AEDs: antiepileptic drugs; EEG: electroencephalography 
Table (2): Laboratory data of the studied children presented by status epilepticus

\begin{tabular}{|c|c|c|}
\hline Laboratory data & Range & Mean \pm SD \\
\hline WBCs $\left(\times 10^{3} / \mathrm{mm}^{3}\right)$ & $3.8-14$ & $7.92 \pm 2.90$ \\
\hline Hemoglobin (gm/dl) & $7.7-14.8$ & $10.90 \pm 1.86$ \\
\hline Platelets $\left(\mathrm{x} 10^{3} / \mathrm{mm}^{3}\right)$ & $118-460$ & $285.84 \pm 98.49$ \\
\hline Total Calcium (mEq/dl) & $6.8-10.2$ & $8.65 \pm 0.88$ \\
\hline Serum glucose (mg/dl) & $78-256$ & $152.06 \pm 49.98$ \\
\hline Urea $(\mathrm{mg} / \mathrm{dl})$ & $10-32$ & $19.55 \pm 4.78$ \\
\hline Creatinine (mg/dl) & $0.2-0.9$ & $0.45 \pm 0.19$ \\
\hline Serum sodium(mEq/dl) & $113-155$ & $134.65 \pm 9.31$ \\
\hline Serum potassium (mEq/dl) & $2.3-6.4$ & $3.62 \pm 0.88$ \\
\hline Serum magnesium (mEq/dl) & $1.8-3.3$ & $2.51 \pm 0.45$ \\
\hline $\operatorname{AST}(\mathrm{mg} / \mathrm{dl})$ & $10-60$ & $29.39 \pm 12.75$ \\
\hline ALT (mg/dl) & $7-50$ & $21.00 \pm 10.87$ \\
\hline C-RP (mg/dl) & $0.4-148$ & $18.90 \pm 31.18$ \\
\hline ESR & $4-120$ & $24.42 \pm 33.09$ \\
\hline $\mathrm{pH}$ & $7.02-7.48$ & $7.36 \pm 0.10$ \\
\hline $\mathrm{HCO}_{3}$ & $10-33$ & $24.92 \pm 5.13$ \\
\hline $\mathrm{PaCO}_{2}$ & $25-71$ & $38.84 \pm 10.56$ \\
\hline
\end{tabular}

ALT: alanine aminotransferase, AST: aspartate aminotransferase

Table (3): Magnetic resonance imaging findings of children presented by status epilepticus

$\begin{array}{lcc} & \text { MRI } & \text { Total (no=31) } \\ \text { Diffuse hypoxia } & & 4(12.9 \%) \\ \text { Encephalitis } & 4(12.9 \%) \\ \text { Delayed myelination } & 1(3.2 \%) \\ \text { Focal cortical dysplasia } & 1(3.2 \%) \\ \text { Mesial temporal sclerosis } & 1(3.2 \%) \\ \text { Normal } & 20(64.5 \%)\end{array}$

Table (4): The outcome of the studied children presented by status epilepticus

\begin{tabular}{l|c}
\multicolumn{1}{c|}{ Outcome } & Total (no=31) \\
\hline Survivors without neurological squeals & $22(70.9 \%)$ \\
\hline Survivors with neurological squeals & $6(19.4 \%)$ \\
\hline Died & $3(9.7 \%)$
\end{tabular}


Table (5): The relation of clinical, laboratory and magnetic resonant imaging findings tothe outcome of status epilepticus

\begin{tabular}{|c|c|c|c|c|}
\hline \multirow[t]{2}{*}{ Item } & \multirow[t]{2}{*}{$\begin{array}{l}\text { Favorableoutcome } \\
\qquad(n=22)\end{array}$} & \multirow[t]{2}{*}{$\begin{array}{c}\text { Unfavorable } \\
\text { outcome }(n=9)\end{array}$} & \multicolumn{2}{|c|}{$\begin{array}{c}\text { Chi square test/ independent } \\
\text { student ttest/ Mann Whitney U } \\
\text { test }\end{array}$} \\
\hline & & & $\mathbf{x}^{2} / \mathbf{t}$ & p-value \\
\hline \multicolumn{5}{|l|}{ Precipitating factors } \\
\hline Unknown & $12(54.5 \%)$ & $1(11.1 \%)$ & \multirow{3}{*}{12.094} & \multirow{3}{*}{$0.017 *$} \\
\hline $\begin{array}{l}\text { Missing Doses } \\
\text { Febrile Illness } \\
\text { Hypoxia }\end{array}$ & $\begin{array}{c}7(31.8 \%) \\
1(4.5 \%) \\
0(0 \%)\end{array}$ & $\begin{array}{l}2(22.2 \%) \\
3(33.4 \%) \\
2(22.2 \%)\end{array}$ & & \\
\hline Inappropriate AED & $2(9 \%)$ & $1(11.1 \%)$ & & \\
\hline \multicolumn{5}{|l|}{ MRI findings } \\
\hline Normal & $16(72.7 \%)$ & $4(44.4 \%)$ & \multirow{2}{*}{2.232} & \multirow{2}{*}{0.135} \\
\hline abnormal & $6(27.3 \%)$ & $5(55.6 \%)$ & & \\
\hline \multicolumn{5}{|l|}{ Type of seizures } \\
\hline Generalized & $17(77.3 \%)$ & $9(100 \%)$ & \multirow{2}{*}{2.439} & \multirow{2}{*}{0.118} \\
\hline Focal & $5(22.7 \%)$ & $0(0 \%)$ & & \\
\hline \multicolumn{5}{|l|}{ Cause of SE } \\
\hline Epilepsy & $20(90.1 \%)$ & $4(44.4 \%)$ & 0.788 & $0.005 * *$ \\
\hline Not epilepsy & $2(9.9 \%)$ & $5(55.6 \%)$ & & \\
\hline \multicolumn{5}{|l|}{ Sex } \\
\hline Male & $16(72.7 \%)$ & $7(77.8 \%)$ & \multirow{2}{*}{0.085} & \multirow{2}{*}{0.771} \\
\hline Female & $6(27.3 \%)$ & $2(22.2 \%)$ & & \\
\hline Age (years) & $5.491 \pm 3.501$ & $5.122 \pm 4.338$ & 0.227 & 0.824 \\
\hline SE Duration (hour) & $10.257 \pm 26.057$ & $9.580 \pm 23.504$ & 0.070 & 0.945 \\
\hline WBCs $\left(x 103 / m^{3}\right)$ & $7.486 \pm 2.863$ & $8.967 \pm 2.873$ & -1.303 & 0.212 \\
\hline Hemoglobin gm/dl & $11.091 \pm 2.010$ & $10.433 \pm 1.432$ & 1.025 & 0.317 \\
\hline Platelets $\left(x 103 / \mathrm{mm}^{3}\right)$ & $271.000 \pm 93.735$ & $322.111 \pm 105.940$ & -1.260 & 0.229 \\
\hline Calcium (mEq/dl) & $8.573 \pm 0.948$ & $8.822 \pm 0.721$ & -0.795 & 0.436 \\
\hline Serum glucose (mg/dl) & $142.455 \pm 49.835$ & $175.556 \pm 44.444$ & -1.816 & 0.087 \\
\hline Urea (mg/dl) & $18.818 \pm 4.625$ & $21.333 \pm 4.950$ & -1.309 & 0.212 \\
\hline Creatinine (mg/dl) & $0.477 \pm 0.207$ & $0.400 \pm 0.112$ & 1.338 & 0.192 \\
\hline Serum sodium (mEq/dl) & $133.000 \pm 9.376$ & $138.667 \pm 8.276$ & -1.663 & 0.115 \\
\hline Serum potassium (mEq/dl) & $3.755 \pm 0.886$ & $3.278 \pm 0.803$ & 1.456 & 0.164 \\
\hline Serum magnesium (mEq/dl) & $2.546 \pm 0.413$ & $2.422 \pm 0.561$ & 0.597 & 0.562 \\
\hline $\mathrm{AST}(\mathrm{mg} / \mathrm{dl})$ & $29.455 \pm 12.850$ & $172.556 \pm 441.590$ & -0.972 & 0.359 \\
\hline ALT (mg/dl) & $20.273 \pm 11.059$ & $139.444 \pm 360.226$ & -0.992 & 0.350 \\
\hline CRP (mg/dl) & $9.182 \pm 9.978$ & $42.667 \pm 49.900$ & -2.924 & $0.019 *$ \\
\hline ESR & $14.818 \pm 24.272$ & $47.889 \pm 41.074$ & -2.347 & $0.047 *$ \\
\hline pH & $7.351 \pm 0.114$ & $7.374 \pm 0.049$ & -0.803 & 0.428 \\
\hline $\mathrm{HCO}_{3}$ & $25.159 \pm 5.755$ & $24.344 \pm 3.326$ & 0.493 & 0.627 \\
\hline $\mathrm{PaCO}_{2}$ & $38.773 \pm 10.619$ & $39.000 \pm 11.068$ & -0.053 & 0.959 \\
\hline
\end{tabular}

SE: status epilepticus; AEDs: antiepilepticdrugs, ESR: erythrocyte sedimentation rate; un-favorable outcome: Survivors with neurological squeals (6 cases) and died ( 3 cases), *: p-value $<0.05$. 


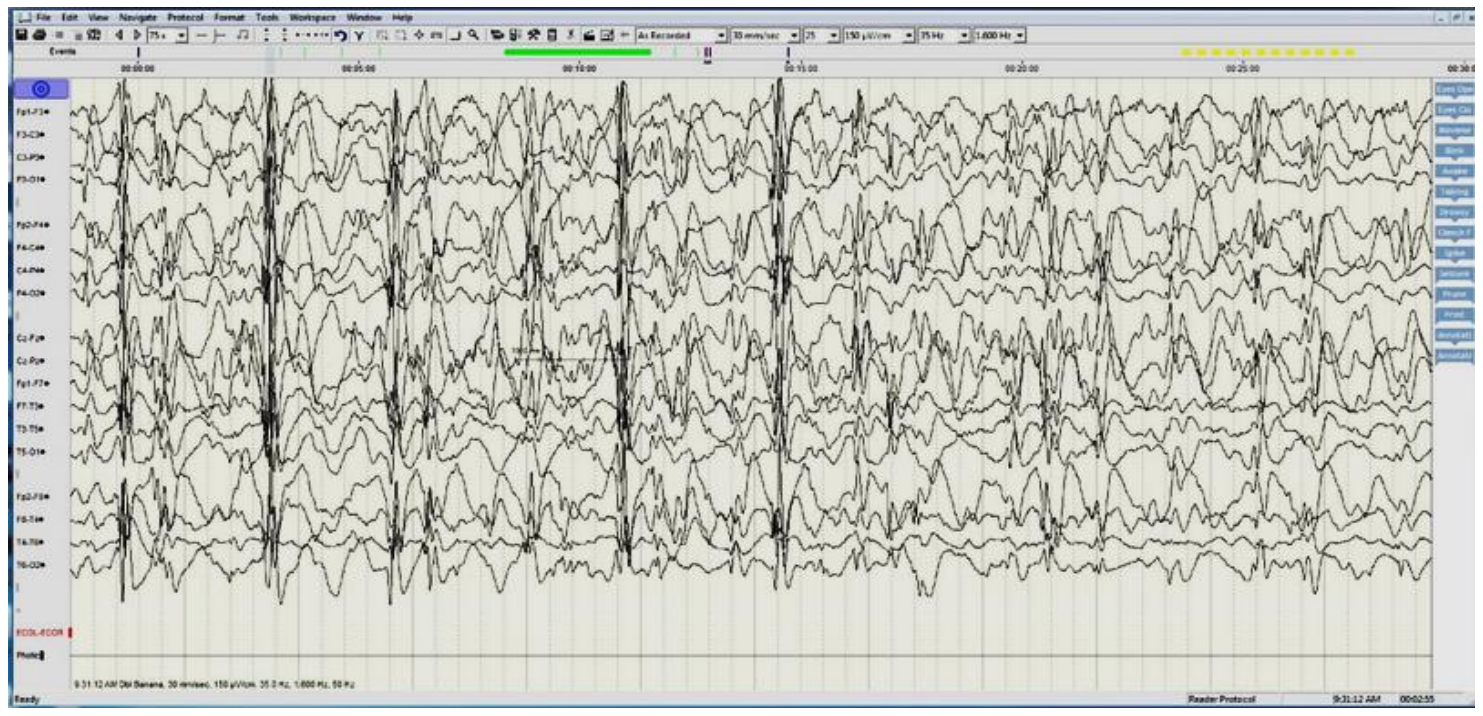

Figure 1: EEG monitors of 5-year male child with convulsive status epilepticus

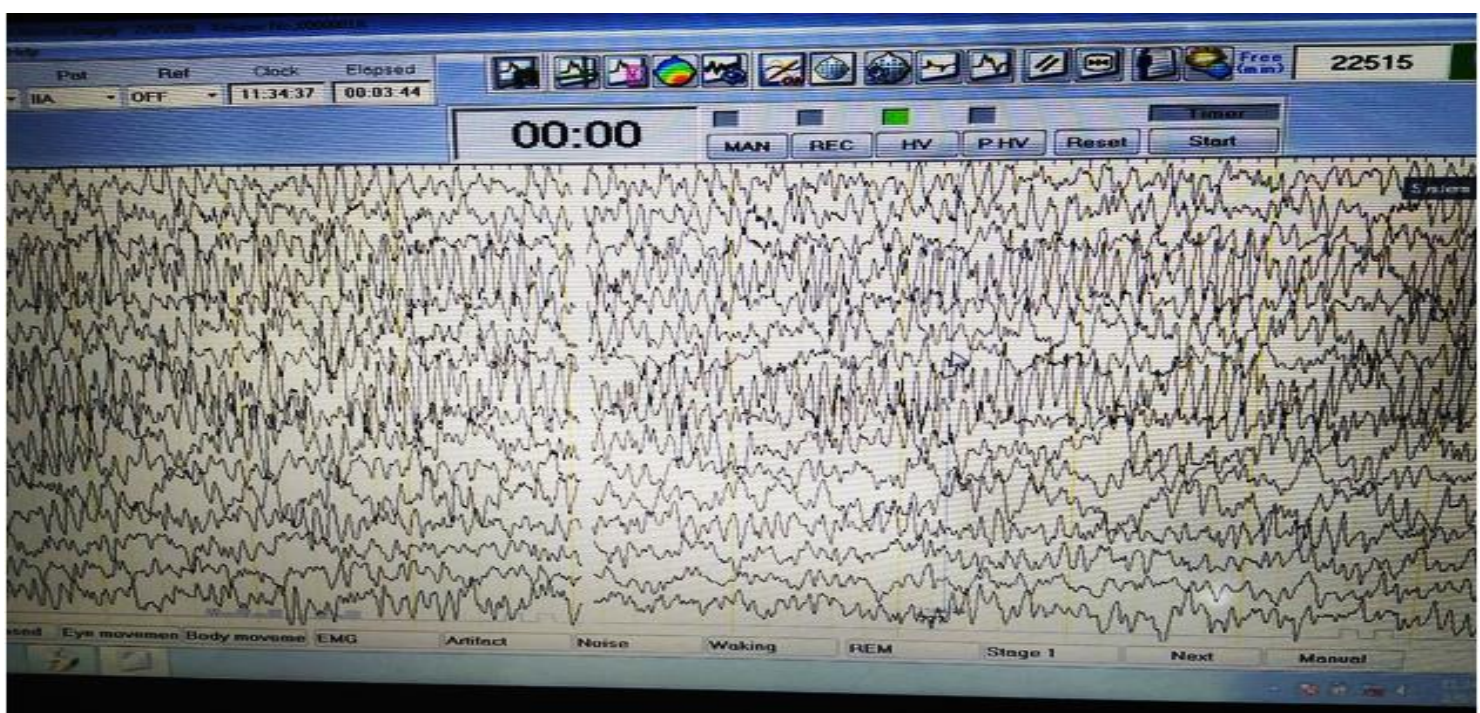

Figure (2): EEG monitor of 8-year-old female with non-convulsve status epilepticus after cessation of convulsve status epilepticus

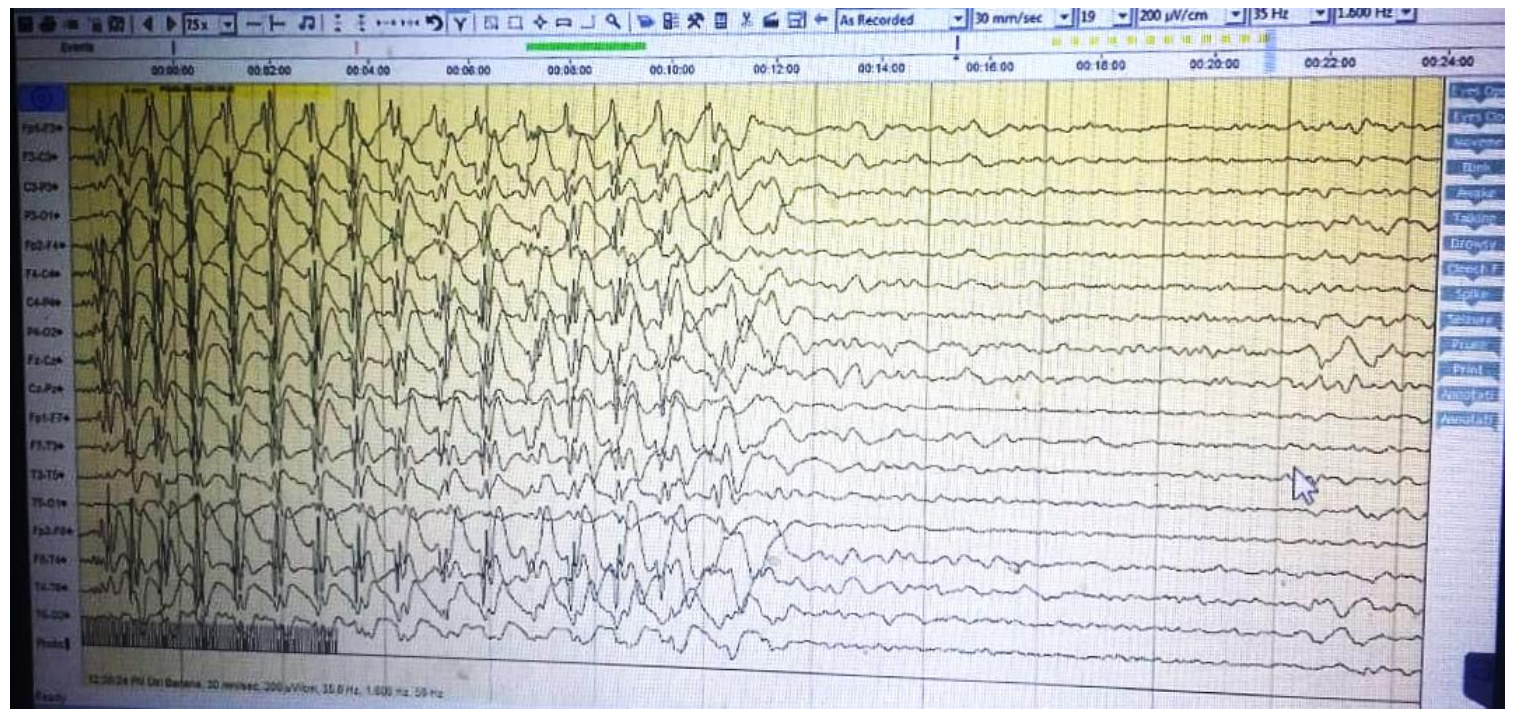

Figure (3): EEG monitor show termination of non-convulsive status epilepticus after midazolam injection (7-yearold male child known case of landau kleffner epileptic syndrome) 


\section{DISCUSSION}

Despite advance in treatment of SE, it is still associated with mortality and morbidity. Identifying the clinical characteristics, pathophysiology and risk factors for poor prognosis is an area of great interest with conflicting results due to the heterogeneity of this disorder ${ }^{[7]}$.

Our study revealed higher incidence of SE is higher in children younger than age of 5 years $(45.2 \%$ were $<2$ years and $32.2 \%$ were $2-5$ years). The male predominance among childrenwith SE in our study agrees with Tiamkao et al. ${ }^{[8]}$ and Dham et al ${ }^{9}$ who reported that males are more likely to suffer from SE than females. Ong et al ${ }^{[10]}$ demonstrated that theage distribution in children with SE showed a higher incidence at under 5 years of age $(10.18 / 100,000$ person-years) and the incidence of SE was higher in males than females with an overall male-to-female rate ratio of 1.57 . The cause for male predominance is unclear. Some studies suggested that hormonal factors may account for the observed gender difference during adolescence. Sex may influence the pathogenesis of developmental brain injuries because immature brain appears to be strongly influenced by the intrinsic difference between male and female brain cells due to their distinct chromosomal complements. ${ }^{[11]}$ The cause for the higher incidence in younger children may be attributed to immature mechanism for control of seizures activity in younger age $^{[12]}$.

Our study revealed high incidence of SE among children with epilepsy (77.4\%); 29\% had SE as 1st presentation $(22.6 \%$ were due to non-epileptic causes while $6.4 \%$ progressed to epilepsy). Similar findings were reported by Bergin et al. [11] who found that about $70 \%$ of children with SE were known cases of epilepsy (29\% were on monotherapy and $42 \%$ were on polytherapy) while $29 \%$ had no previous seizure attacks and SE was an initial presentation. The frequency of epilepsy in our study is much more than Nishiyama et al. ${ }^{[13]}$ who found that $34(28.3 \%)$ of the 120 patients had been diagnosed with epilepsy. Das et al. ${ }^{[14]}$ reported that $63.82 \%$ of children who developed SE were younger than five years of age and $64.9 \%$ of children presented by SE as the first attack of seizure and $35.1 \%$ had previously repeated seizures; drug default was the main predisposing factor for SE in $42.4 \%$ of children. This contradiction could be explained by differences in definitions, classification of seizures, and etiologic criteria in epidemiological studies on epilepsy have often yielded discordant results between studies leading to controversial results that reflect differences in genetically determined susceptibility ${ }^{[12] \text {. }}$

Regarding the characteristics of seizures in children presented by SE, generalized seizures were the predominant form of convulsion among our studied children with no significant association between the type of seizures and the outcome. In accordance with our findings, Kumar et al. ${ }^{[15]}$ demonstrated that generalized seizures are the predominant type of convulsionin children presented by SE $(91 \%)$. Das et al. ${ }^{[14]}$ found no significant difference between the mortality and the type of seizures.

Our study showed that missed dose of antiepileptic medications or using inappropriate type of antiepileptic drugs (AEDs) were the commonest precipitating factor for SE in childrenwith epilepsy while hypoxia and febrile illness were more common in non-epileptic children. Prognosis was significantly worse in non-epileptic children; hypoxia and encephalitis have the highest morbidity and mortality. As acute phase reactants level increased during infection, so it was not a surprise that elevated ESR, and CRP are associated with worse outcome. Supporting our findings Sculier et al. ${ }^{[16]}$ concluded that etiology of SE is the main determinant of outcome, and the effect of age or SE duration is often difficult to distinguish from the underlying cause. Kravljanac et al. ${ }^{[17]}$ found that neurologic sequels occurred in $12.9 \%$ of children with SE and mortality rate was $9.3 \%$. Etiology and prior neurologic abnormalities were the major predictors of poor outcome. Sutter et al. ${ }^{[18]}$ demonstrated that increased C- reactive protein levels at status epilepticus onset were associated with higher rates of refractory SEs and death (with every $1 \mathrm{mg} / \curvearrowright$ : odds ratio $1.01,95 \%$ confidence interval 1.00- 1.02, $\mathrm{p}=0.021$; odds ratio $1.01,95 \%$ confidence interval 1.00-1.02, $\mathrm{p}<0.007$, respectively).

As this study was single center study, so a major limitation of the current study is the small number of included children. Further large-scale studies are required to identify children at higher risk to develop $\mathrm{SE}$ and those with poor outcome to allow early optimal intervention.

\section{CONCLUSION}

Despite that epilepsy is the main cause of SE, nonepileptic causes are more serious and are associated with worse outcome. Male gender, poor compliance to antiepileptic medications and febrile illness are linked to development to SE in children. SE induced by hypoxia and encephalitis has the highest morbidity and mortality.

Conflict of interest: No direct or indirect conflict of interest

Financial support: This work not funded from any governmental or non-governmental agencies. 


\section{REFERENCES}

1. Gurcharran $\mathbf{K}$ and Grinspan ZM. The burden of pediatric status epilepticus: Epidemiology, morbidity, mortality, and costs. Seizure, 2019;68:3-8.

2. Trinka E, Cock H, Hesdorffer D, Rossetti AO, Scheffer IE, Shinnar S, et al. A definition and classification of status epilepticus--Report of the ILAE Task Force on Classification of Status Epilepticus. Epilepsia, 2015;56(10):1515-23.

3. Jafarpour S, Stredny CM, Piantino J, and Chapman KE. Baseline and outcome assessment in pediatric status epilepticus. Seizure, 2019;68:52-61.

4. Pujar S and Scott RC. Long-term outcomes after childhood convulsive status epilepticus. Curr Opin Pediatr, 2019;.31(6):763-768.

5. Scott RC. What are the effects of prolonged seizures in the brain? Epileptic Disord, 2014;16 (1): S6-11.

6. Stredny CM, Abend NS, and Loddenkemper T. Towards acute pediatric statusepilepticus intervention teams: Do we need "Seizure Codes"? Seizure, 2018; 58:133-140.

7. Arun PT, Shruthi TK, Rajakumar PS, and Shuba S. Profile on status epilepticus, clinical features and lab parameters and outcome in pediatric intensive care. International Journal of Contemporary Pediatrics. Int J Contemp Pediatr, 2017; 4(4):13101316.

8. Tiamkao S, Pranbul S, Sawanyawisuth $\mathbf{K}$ and Thepsuthammarat K. Integrated Epilepsy Research G. A national database of incidence and treatment outcomes of status epilepticus in Thailand. Int $\mathbf{J}$ Neurosci, 2014;124: 416-420.

9. Dham BS, Hunter $K$ and Rincon $\mathbf{F}$. The epidemiology of status epilepticus in the United States. Neurocrit Care, 2014; 20: 476-483.

10. Ong CT, Sheu SM, Tsai CF, Wong YS, and Chen SC. Age-dependent sex difference of the incidence and mortality of status epilepticus: a twelve-year nationwide population-based cohort study in Taiwan. PLoS One, 2015;10(3): e0122350.

11. Bergin PS, Brockington A, Jayabal J, Scott S, Litchfield R, Roberts L, et al. Status epilepticus in Auckland, New Zealand: Incidence, etiology, and outcomes. Epilepsia, 2019; 60(8):1552-1564.

12. Chin RF, Neville BG, and Peckham C. Incidence, cause, and short-term outcome of convulsive status epilepticus in childhood: prospective populationbasedstudy. Lancet, 2006;368:222-229. 9531

13. Nishiyama I, Ohtsuka Y, Tsuda T, Kobayashi K, Inoue $\mathbf{H}$, Narahara $\mathbf{K}$, et al. An epidemiological study of children with status epilepticus in Okayama, Japan: incidence, etiologies, and outcomes. Epilepsy Res, 2011; 96(1-2):89-95.

14. Das K, Das SK, Pradhan S, Sahoo PI, Mohakud NK, Swain A, et al. Clinical Feature and Outcome of Childhood Status Epilepticus in a Teaching Hospital, Odisha, India. Cureus, 2020;12(10): e10927.

15. Kumar M, Kumari R, and Narain NP. Clinical Profile of Status epilepticus (SE) in Children in a Tertiary Care Hospital in Bihar. J Clin Diagn Res, 2014; 8(7): PC14-7.

16. Sculier C, Gaínza-Lein M, Sánchez Fernández I, and Loddenkemper $\mathbf{T}$. Long- term outcomes of status epilepticus: A critical assessment. Epilepsia, 2018; 59 (2):155-169.

17. Kravljanac R, Jovic N, Djuric M, Jankovic B, and Pekmezovic T. Outcome of status epilepticus in children treated in the intensive care unit: a study of 302 cases. Epilepsia, 2011;52(2):358-63.

18. Sutter R, Grize L, Fuhr P, Rüegg S, and Marsch S. Acute-phase proteins and mortality in status epilepticus: a 5-year observational cohort study. Crit Care Med, 2013; 41(6):1526-33. 


\section{الألخص العربي \\ الخصائص السريريه و نتائج الاطفال المصابين بحالة الصرع المتشنيه

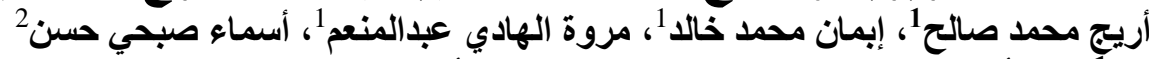

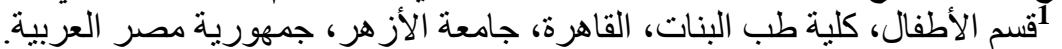

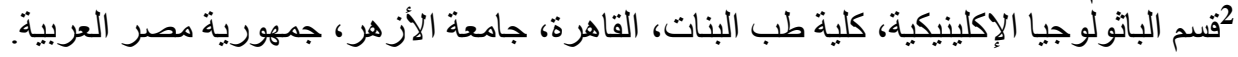

ملخص البحث

الخلفية: تمثل التشنجات المستمرة حاله طارئه و خطيرة في طب الاعصاب حيث ترتبط بزيادة حدوث

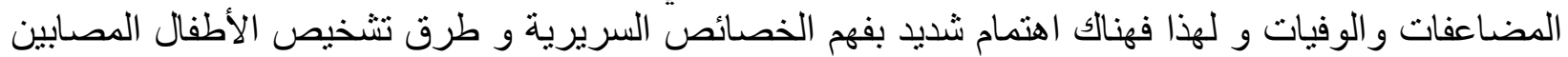
بنوبات نشنجات مستمرة

الهدف: التعرف على الاعر اض السريريةو المظاهر التشخيصي للأطفال الذين يعانون من تشنجات مستمرة. الطرق: اجريت هذه الدراسة التحليلية الوصفية على 31 طفلاً يعانون من تشنجات مستمرة استوجبت إدخالهم إلى إلى وحدة العناية المركزة للأطفال. تم رصد الاعر اض السرية الإية و و عمل صوره دم كامله و قياس البروتين التفاعلي

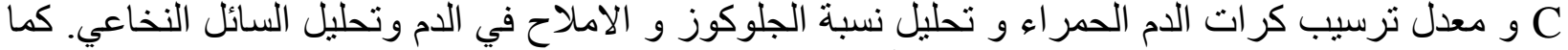
تم إجراء التصوير بالرنين المغناطيسي لجميع الأطفال المشمولين في الدر اسة.

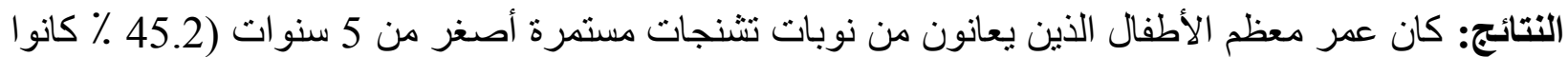

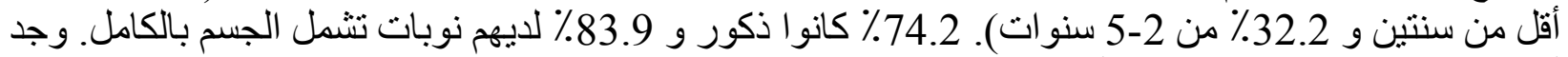

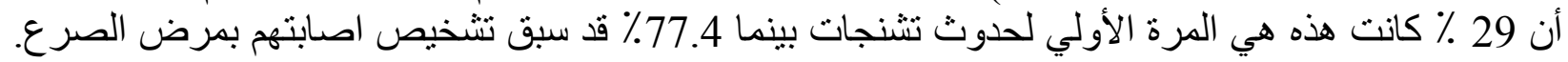

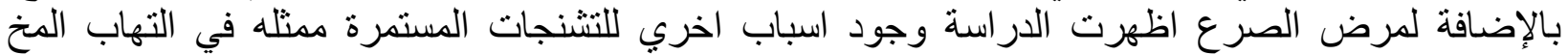
(12.9\%) و التشنج الحراري (5.5\%) ونقص الأكسجين الحاد (الاختناق) (3.2\%). كان العامل المحفز الرئيسي

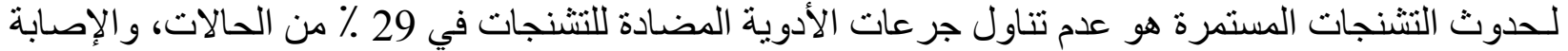

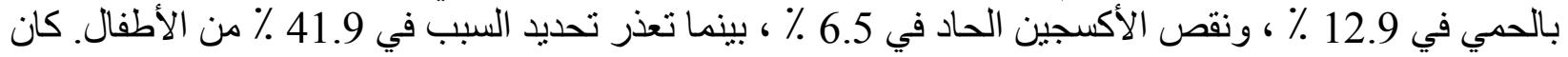

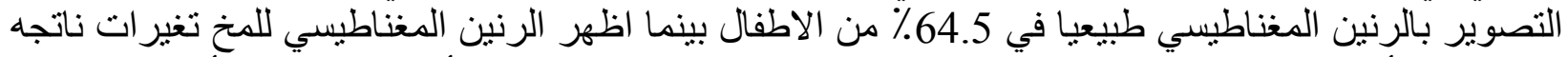

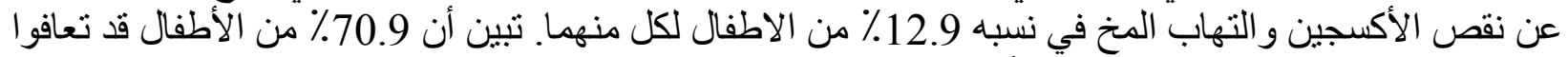

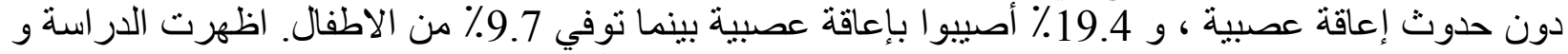
جود ارتباط كبير بين المسببات غير الصربة عية و الحمى ونقية ونص الأكسجين وارتفاع دلالات الالتهاب في الدام

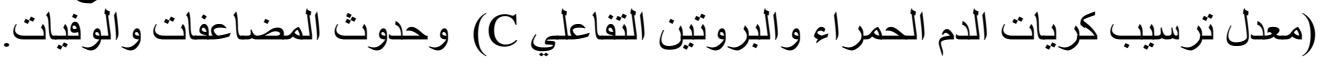

الأستتتاجات: على الرغم من أن الصرع هو السبب الرئيسي لنوبات التشنجات المستمرة ، إلا أن المسببات غير

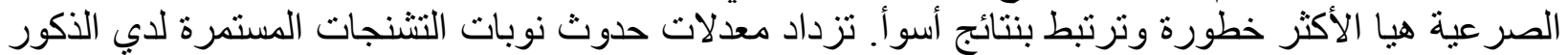

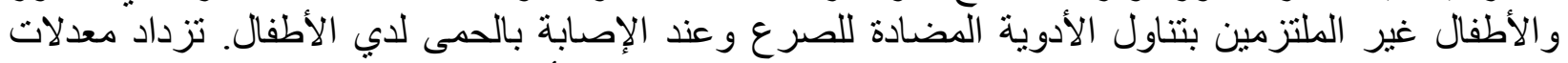
المضاعفات و الوفيات في حالات التشنجات المستمرة الناتجة عن نقص الأكسجين و التهاب المخ في في الاطفال.

الكلمات المفتاحية: تشنجات مستمرة، التشنجات، النتيجة، الأطفال.

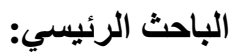

الاسم: مروة الهادي عبدادي: المنعم

الهاتف: 01022424667

البريد الأكتروني: marwaelhady@azhar.edu.eg 